\title{
The P-Star Model of Inflation and Its Performance for the Kenyan Economy
}

\author{
Moses C. Kiptui ${ }^{1}$ \\ ${ }^{1}$ Research Centre, Kenya School of Monetary Studies, Nairobi, Kenya \\ Correspondence: Moses C. Kiptui, P.O. Box 65041-00618, Ruaraka, Nairobi, Kenya. Tel: 254-20-8646-217. \\ E-mail: kiptuimc@ksms.or.ke or moses.kiptui@yahoo.com
}

Received: June 11, 2013

Accepted: June 10, 2013

Online Published: August 26, 2013

doi:10.5539/ijef.v5n9p82

URL: http://dx.doi.org/10.5539/ijef.v5n9p82

\begin{abstract}
The aim of this study was to extend the P-Star methodology by applying an alternative approach to the derivation of the foreign price gap; to estimate the P-Star model using Kenyan data over the period from 1960 to 2011 and finally, to compare the forecasting performance of the P-Star model with alternative inflation models. The results from the estimated P-Star model show that the domestic price gap has highly significant positive effects on inflation in Kenya with the implied result that a 1 per cent increase in domestic price gap leads in the subsequent period to an increase in inflation by 0.5 per cent. On the other hand, the foreign price gap was found to have insignificant effects on inflation. When forecasts from the P-Star model are compared with forecasts from alternative inflation models, the P-Star model outperforms these models. Policy wise, the results in this study underscore the usefulness of the P-Star model in providing forecasts of inflation for Kenya.
\end{abstract}

Keywords: P-Star Model, inflation, price gap, exchange rate, output gap, Kenya, forecast evaluation

\section{Introduction}

Inflation forecasting is considered crucial for monetary policy operations given the need to control inflation and ensure minimal deviation from target. Kenya is no exception in this respect as the country has in the past suffered major setbacks on the inflation front yet at the same time striving to maintain a target level of inflation as prescribed by the authorities. The country experienced double digit inflation on many occasions since 1974 (figure 1). The highest level of inflation ever experienced was however in 1993 when inflation rose to 46 per cent. Due to the incessant macroeconomic instability in the 70's and 80's the Kenya Government embraced radical reforms under the IMF and World Bank structural adjustment programs. The reforms led to interest rate decontrols in 1991, liberalization of the exchange rate in 1993 and the repeal of the Exchange Control Act in 1995. Price stability has been maintained since then and it is only recently that inflationary pressures have again been felt owing to several factors. These include the post election violence of 2008 which disrupted supplies, the global financial crisis as well as the recent euro-zone crisis. The crises have resulted in frequent inflationary pressures with inflation for instance rising to 26 per cent in 2008. Inflation therefore remains the country's major concern and is monitored closely by the monetary authorities; hence the need to come up with a framework for forecasting and monitoring inflation in Kenya. The P-Star model presents such an opportunity to predict inflation and could provide a forecasting solution as required by monetary authorities.

The P-Star model of inflation, proposed by Hallman, Porter \&Small (1991) follows the quantity theory of money. P-Star in itself represents the equilibrium price level, that is, the price level which is consistent with prevailing level of money supply given potential output $\left(\mathrm{y}^{*}\right)$ and long-run velocity of money $\left(\mathrm{v}^{*}\right)$. The P-Star model postulates that the deviation between actual price level (P) and equilibrium price level (P-Star or simply $\mathrm{P}^{*}$ ) determines inflation in the economy. If actual price level falls below the equilibrium price level, prices will be expected to rise thus suggesting an increase in inflation. Prices will rise until equilibrium is restored. On the other hand, if prices rise above equilibrium price level, prices will be expected to decline thus suggesting a decline in inflation. This decline in prices occurs to restore prices to equilibrium level. Thus, the gap between the actual price level and the equilibrium price level, referred to in this case as the "domestic price gap" determines the rate of inflation. How close this relationship is remains an empirical issue. 


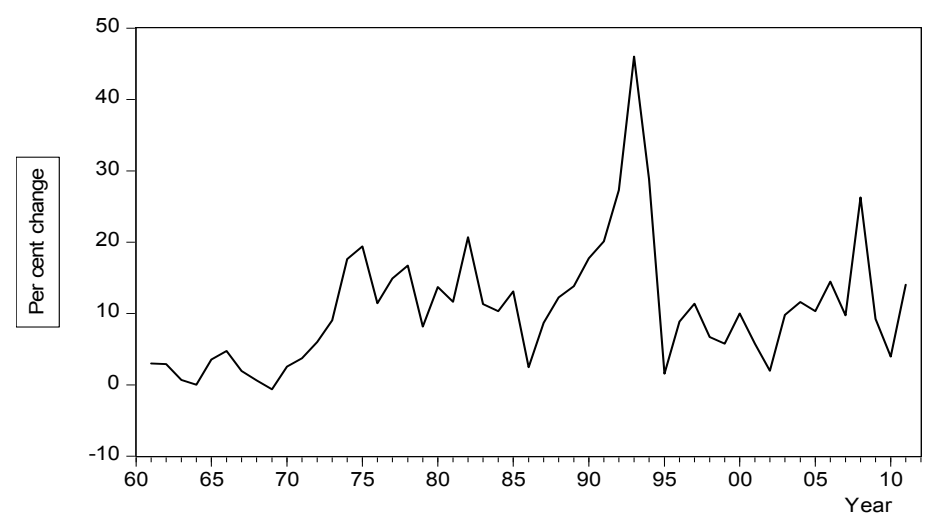

Figure 1. Kenya's infiation rate: 1960-2011

The P-Star model has been tested in a number of countries. In some, the P-Star model is a great success in predicting inflation or just as good as other models in forecasting. Subsequent research has applied different versions of the P-Star model. In some studies the price gap has been decomposed to reflect disequilibrium in the money market $\left(\mathrm{v}^{*}-\mathrm{v}\right)$ and disequilibrium in the goods market $\left(\mathrm{y}-\mathrm{y}^{*}\right)$. Thus, the price gap is a comprehensive indicator of inflationary pressure which combines information on the goods market (output gap) and the money market (liquidity gap). It is therefore an extended relationship. The impact of monetary policy on inflation is transmitted through real demand or the output gap. Some early studies (e.g. Kool and Tatom, 1994) indicated that the P-Star model achieved more favorable results in large developed economies. The dismal performance in small open economies was attributed to major effects of imported inflation in these economies. Thus, subsequent studies tried to resolve this problem by incorporating a measure of the foreign price gap in addition to the domestic price gap in order to improve the performance of the P-Star model in small open economies. In this respect, consideration of the foreign price gap is relevant in examining inflation dynamics in Kenya. In the literature, the foreign price gap has been derived borrowing heavily from purchasing power parity (PPP) relationships.

The purpose of this study is therefore threefold: to extend the P-Star methodology by applying an alternative approach to the derivation of the foreign price gap; secondly, to estimate the P-Star model using Kenyan data over the period from 1960 to 2011 in order to test the relevance and performance of the P-Star model in the Kenyan context and finally, to compare the forecasting performance of the P-Star model with alternative inflation models. This study fills an existing gap in the literature since there are very few studies examining the performance of the P-Star model in developing economies and no such study has been undertaken for Kenya.

This study is organized as follows: section 2 below reviews literature; sections 3 and 4 discuss the methodology and data used in analysis, respectively. Section 5 discusses the empirical results and their interpretations while section 6 concludes the study and presents a brief discussion of policy implications.

\section{Overview of the Literature}

Empirical analysis initially revolved around assessing the theoretical underpinnings of the P-Star model, while at the same time evaluating the significance of alternative measures of the price gap. In fact, while advancing the P-Star model, Hallmark, Porter and Small (1991) argued that the P-Star approach provides a reference point that takes into account all past money growth so that the P-Star model becomes more relevant in assessing long-term price developments. Atta-Mensah (1996) examined this view by testing the significance of cumulative growth of M1 and the deviations of M1 from its long-run path within the framework of the P-Star model. The study concludes that the cumulative growth of M1 and M1 gaps are useful for predicting the long-run path of inflation thus validating the P-Star approach. Scheide and Trabandt (2000) considered two main methods for calculating the price gap in the Euro Area: a long-run money demand function estimated in which the price gap is just the residual and the equilibrium values of output and velocity which are used to define the price gap. They found the residual not a driving force in the inflation process and therefore adopted the latter measure of price gap. Many studies consider the price gap as a whole but also use in analysis the decomposed price gap into output gap and liquidity gap (i.e. deviation of velocity from long-run level).

Some early studies such as Kool and Tatom (1994) found that the original P-Star methodology as introduced by Hallmark, Porter and Small (1991) worked well for large advanced economies and not very well for small open 
economies. Consequently, Kool and Tatom attributed this finding to the likely effects of imported inflation in these economies. Since then, the foreign price gap was introduced to account for these external factors. Going by the formulation in Kool and Tatom, (1994), the foreign price gap applies more to countries pursuing fixed exchange rates or countries that observe a peg of the domestic currency to that of a dominant global currency such as the dollar. It could still apply in a liberalized exchange rate regime such as Kenya's since despite liberalization of the exchange rate in Kenya the public continues to monitor the Kenya Shilling-US dollar exchange rate expecting monetary authorities to intervene whenever the exchange rate experiences major fluctuations. Policy analysts and the public at large thus push for stability in the exchange rate which if strictly done would produce an unannounced peg to the US dollar. These are the considerations in Kool and Tatom (1994) while extending the P-Star model to incorporate the foreign price gap as their study considers the case of one large country which provides an anchor for the system. By setting its monetary policy to achieve own domestic goals, the dominant country provides an anchor for smaller economies. Small economies take the anchor country's monetary policy as given and commit themselves to a fixed exchange rate objective. Thus, a price gap determined abroad through the exchange rate constraint is expected to influence domestic inflation. Kool and Tatom show that in these circumstances monetary authorities do not determine their own long-run price level. Instead their long-run equilibrium price level is imported from countries whose currency is the basis of the peg. By incorporating the foreign price gap, they were able to improve the model's fit for all the economies studied. The findings by Kool and Tatom (1994) and subsequent applications of their approach thus emphasize the importance of accounting for imported inflation in the study of inflation dynamics in developing economies.

The significance of the price gaps (domestic and foreign) as evaluated in various studies has yielded strong support for the P-Star model. Application of the P-Star model by Tsionas (2000) incorporating both domestic and foreign price disequilibria was found to work quite well in the case of the Greek economy. Foreign and domestic price disequilibria were found to be important determinants of Greek inflation. However, domestic disequilibria were found considerably important. Scheide and Trabandt (2000) use the price gap as the long-run relationship and other variables are added to the regression to capture the short-run dynamics. The resulting loading coefficient of the price gap is quite high (i.e. 0.18). It implies that a price gap of one per cent today leads to almost 0.2 per cent more inflation in the next quarter. The response of consumer prices to the price gap is strongly positive. Other factors such as raw material prices and unit labour costs also have some explanatory power. Qayyum and Bilquees (2005) show that compared to the simple autoregressive model and the M2 growth augmented model, the P-star model can be used to obtain the leading indicator of inflation in Pakistan because it has additional information about the future rate of inflation. Pallardo and Esteve (1999) tested the performance of the P-Star model for the Spanish economy and as expected, the coefficient on the price gap (P-P*) is strongly significant and negative. Results show that the model works reasonably well at explaining short-run dynamics for prices. Frait, Komárek and Kulhánek (2000) applied the P-Star model to a time series from the period 1991 to 1998. They conclude that the inflation dynamics in the Czech Republic follow the premises of the P-Star model. The foreign component of the price gap seems to be more relevant than the domestic one. This result confirms the hypothesis that equilibrium price level in the Czech Republic is significantly affected by German monetary policy through the explicit and implicit connection of the Koruna's exchange rate to the DEM or later the Euro.

A number of studies have also evaluated the forecasting performance of the P-Star model. In some countries, the P-Star model turns out a more powerful tool compared to other models while in other countries it is just as good. Qayyum and Bilquees (2005) find that the P-Star based indicator of inflation performs better than autoregressive models and M2 growth indicator in forecasting future inflation. Hallman, Porter and Small (1991) evaluated actual and forecasted inflation rates for various models. The study finds that the forecast from the price gap model contains useful information beyond that contained in the forecasts from the other models. Christiano (1989) argue that in terms of the square root of mean squared error (RMSE) the P-Star model outperforms the T-bill model at all horizons. However, in terms of bias and average absolute error the T-bill model outperforms the P-Star model at all forecast horizons. Hoeller and Poret (1991) tested in-sample tracking ability and forecasting performance of P-Star model for 20 OECD countries. For most countries, P-Star equations outperform other simple financial-market-based inflation models.

\section{Methodology}

The starting point in the analysis of the P-Star model of inflation is the quantity theory of money which is of the form.

Where, $\mathrm{M}$ is money Stock

$$
M_{t} V_{t}=P_{t} Y_{t}
$$




\section{$\mathrm{V}$ is velocity}

$\mathrm{P}$ is domestic price level

$\mathrm{Y}$ is real output

Equation (1) can be rewritten as price equation,

$$
P_{t}=\frac{M_{t} V_{t}}{Y_{t}}
$$

Taking the equilibrium price level consistent with money supply, $\mathrm{M}$, to be $\mathrm{P} *$ and considering that $\mathrm{P}^{*}$ corresponds to potential or equilibrium output and the long-run level or equilibrium velocity, equation (2) can be rewritten as,

$$
P_{t} *=\frac{M_{t} V_{t}^{*}}{Y_{t}^{*}}
$$

Where the asterisk represents equilibrium value or long-run level of the variable;

Dividing through by $P_{t}=\frac{M_{t} V_{t}}{Y_{t}}$ we obtain,

$$
\frac{P_{t}^{*}}{P_{t}}=\frac{M_{t} V_{t}^{*}}{M_{t} V_{t}} \times \frac{Y_{t}}{Y_{t}^{*}}
$$

Taking natural logs and redefining the variables and using small letters for the log form of the variables, we have,

$$
p_{t}^{*}-p_{t}=\left(v_{t}^{*}-v_{t}\right)+\left(y_{t}-y_{t}^{*}\right)
$$

Equation (5) decomposes the price gap ( $\mathrm{p}^{*}$-p) into velocity gap ( $\left.\mathrm{v}^{*}-\mathrm{v}\right)$ and output gap $\left(\mathrm{y}-\mathrm{y}^{*}\right)$.

To relate the price gap to inflation, an error correction model is adopted to combine the long-run component and the short run dynamics. Hence,

$$
\Delta P_{t}=\alpha_{0}+\alpha\left(p_{t-1}^{*}-p_{t-1}\right)+\sum_{t=1}^{n} \beta_{i} \Delta p_{t-i}+\varepsilon_{t}
$$

$\alpha$ is the speed of adjustment of prices to long run price level, $P_{t}^{*}$.

Equation (6) is a conventional error correction model (ECM) and has been applied in empirical analysis by also expanding the price gap in the manner stated in equation (5). Equation 6 predicts that if $P_{t}$ is below $P_{t}^{*}$, inflation will rise as actual price level adjusts upwards towards its equilibrium level. Conversely, if $P_{t}$ is above $P_{t}^{*}$, inflation will fall due to the downward adjustment of prices towards equilibrium. Similarly, no change in inflation occurs if $P_{t}=P_{t}^{*}$. In brief, the price gap predicts the direction of movement of inflation and hence is a good indicator of inflation.

The price gap discussed so far is the domestic price gap. Going by the significance of foreign price gap in a number of studies already discussed in this paper, equation (6) needs to be extended to include a foreign price gap. The foreign price gap has been discussed extensively in Kool and Tatom (1994). They derived a foreign price gap based on monetary approach to balance of payments. In this paper we deviate somehow by examining instead the link between competitiveness and inflation, following the approach in Kamin and Klau (2003) thus allowing for an alternative derivation of the foreign price gap. In this latter approach, a small open economy is considered which basically produces, consumes and exports a home good whose price in domestic currency is $\mathrm{P}^{\mathrm{H}}$. The small open economy also imports and consumes a foreign good. The adjustment in home prices is attributable to aggregate demand changes. The price of the foreign good given in domestic currency is $\mathrm{P}^{\mathrm{F}}$ which in effect is foreign price stated in foreign currency multiplied by the nominal exchange rate. The real exchange rate is therefore given as $P^{F} / P^{H}$. Using an asterisk to denote and distinguish the equilibrium real exchange rate level from the actual level, the equilibrium (or long-run) real exchange rate can be given as $P^{F^{*}} / P^{H^{*}}$. An increase in the real exchange rate defined in this manner represents depreciation while a decrease represents an appreciation. Assuming a partial adjustment of actual real exchange rates to its long-run level or equilibrium,

$$
\log \left(\frac{P_{t}^{F}}{P_{t}^{H}}\right)=\log \left(\frac{P_{t-1}^{F}}{P_{t-1}^{H}}\right)+\lambda\left[\log \left(\frac{P_{t-1}^{F^{*}}}{P_{t-1}^{H *}}\right)-\log \left(\frac{P_{t-1}^{F}}{P_{t-1}^{H}}\right)\right]
$$


It can be shown after some manipulation that changes in home prices (inflation) relate to foreign prices and also the deviation between actual and equilibrium real exchange $\operatorname{rates}^{1}$, that is,

$$
\Delta \log P_{t}^{H}=\Delta \log P_{t}^{F}+\lambda\left[\log \left(\frac{P_{t-1}^{F}}{P_{t-1}^{H}}\right)-\log \left(\frac{P_{t-1}^{F^{*}}}{P_{t-1}^{H^{*}}}\right)\right]
$$

$\lambda$ is the adjustment coefficient and takes values between 0 and $1.1 / \lambda$ is the speed of adjustment. Equation (8) states that if the actual real exchange rate rises above equilibrium value, prices of home goods increase, resulting in inflation. Thus, deviation of the real exchange rate above equilibrium level leads to build-up of inflationary pressure. The measure of foreign price gap being proposed is therefore the real exchange rate deviation from equilibrium. In figure 2, the proposed measure is shown to be very close to the measure initially proposed by Kool and Tatom (1994) and applied by Tsionas (2001) and Frait et al (2000) among others².

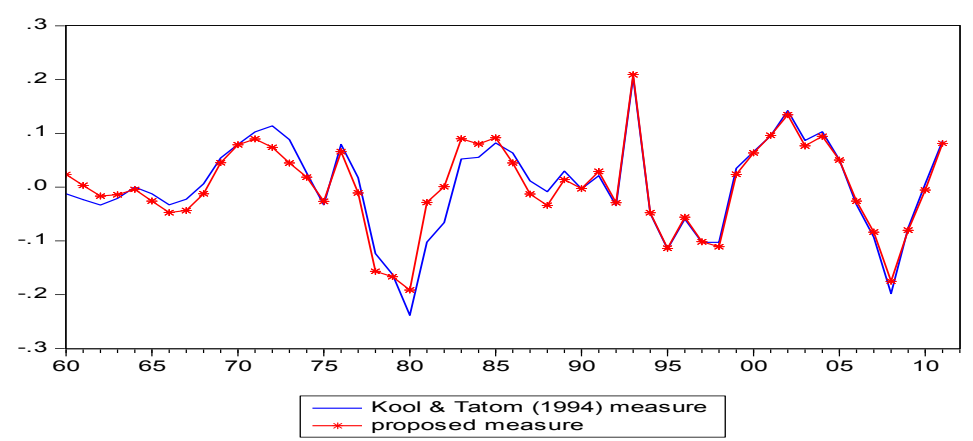

Figure 2. Measures of the foreign price gap for Kenya: Kool and Tatom (1994) versus proposed measure

This study therefore incorporates the foreign price gap which can be redefined for ease of presentation as $\left(\right.$ rer $_{t-1}-$ rer $\left._{t-1}^{*}\right)$. Hence, equation (6), can be rewritten to yield the following dynamic equation to be estimated in the study,

$$
\Delta_{t}=\alpha_{0}+\alpha_{1}\left(p_{t-1}-p_{t-1}^{*}\right)+\alpha_{2}\left(r e r_{t-1}-r e t_{t-1}^{*}\right)+\sum_{i=1}^{n} \beta_{i} \Delta p_{i}+\sum_{j=1}^{m} \delta_{j} \Delta v e r_{j}+\tau_{i} Z_{i}+\varepsilon_{t}
$$

Where rer is actual level of the real exchange rate and rer* is the equilibrium real exchange rate.

Equation (9) incorporates both domestic and foreign price gaps. However, other exogenous variables (represented by $Z_{\mathrm{i}}$ ) will be included to proxy for foreign shocks (i.e. changes in world commodity and fuel prices) and domestic factors (i.e. foreign exchange market liberalization, post-election violence, etc.) with potential to contribute to domestic inflationary pressure.

\section{Data}

Data is obtained from the World Bank African Development Indicators. The definition of variables is given in table 1. The data obtained from the World Bank are GDP in constant prices, money supply $\left(\mathrm{M}_{2)}\right.$ and Kenya consumer price index (CPI). From the International Financial Statistics of the IMF are obtained nominal exchange rate for the Kenya shilling - US Dollar and US consumer price index. The United States, being a large economy is considered to proxy for the rest of the world.Therefore the real exchange rate (rer) is obtained by taking the product of the nominal exchange rate and US CPI and dividing by Kenya's CPI.

The domestic price gap has been defined as the difference between the log of CPI and the trend of log of CPI. The trend of $\log$ CPI is derived using the Hodrick -Prescott Filter with a smoothing parameter of 100. A similar approach is applied to derive output gap by computing the difference between the log of real output and the trend of log real output as derived using Hodrick- Prescott Filter. As argued byLim and Papi (1997) the difference between actual and equilibrium real exchange rates provide a measure of disequilibrium in the external sector that impacts on price developments. The expected sign of exchange rate disequilibrium is positive; when real exchange rate is more depreciated than its long run level, upward pressure on inflation follows. In this study, a partial adjustment process to equilibrium of the real exchange rate is assumed such that deviations from equilibrium real exchange rate are expected to impact positively on prices and inflation. The Hodrick-Prescott 
filter is used to derive the long-run level of the real exchange rate. The difference between observed real exchange rates and the estimated long-run values represent deviations from equilibrium or foreign price gap (rer-rer*).

Table 1. Definition of variables

\begin{tabular}{ll}
\hline Variable & Definition \\
\hline $\mathrm{M}$ & Money supply, $\mathrm{M}_{2}$ \\
$\mathrm{P}$ & Consumer Price Index, CPI \\
$\mathrm{Y}$ & Real GDP \\
$\mathrm{P}-\mathrm{P}^{*}$ & Domestic Price Gap (Log CPI -Log CPI trend) \\
rer-rer $^{*}$ & Foreign price gap (log RER-logRERtrend) \\
Oilp & World oil price \\
$\mathrm{FDP}$ & World food price \\
YGAP & Output gap (y-y*) \\
DUM1993 & $\begin{array}{l}\text { Dummy variable to proxy for foreign exchange market liberalization; 1993=1, zero } \\
\text { otherwise }\end{array}$ \\
DUM2008 & $\begin{array}{l}\text { Dummy variable to proxy for post-election violence with negative supply effects; } 2008=1, \\
\text { zero otherwise }\end{array}$ \\
\hline
\end{tabular}

\section{Empirical Results and Interpretations}

In figure 3, the log of CPI is compared with the log of P-star. The deviation between the two is shown in figure 4 and compared with actual inflation series. Although there was major deviation between CPI and P-star in the early 90's, a strong positive relationship between the two series is visible albeit with a lag over some periods. The relationship between foreign price gap and inflation as shown in figure 5 is however not very clear as it tends to be negative over most of the period. One can note however the strong positive relationship in the early 90 's during the exchange rate liberalization interval.

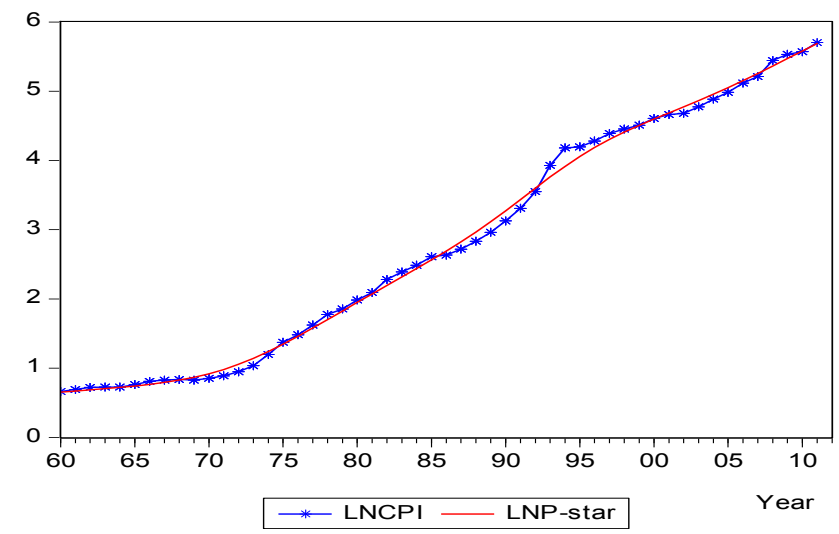

Figure 3. Logaritmic values of consumer price index $(\ln \mathrm{P})$ and $\mathrm{P}-\mathrm{Star}\left(\ln \mathrm{P}^{*}\right)$ 


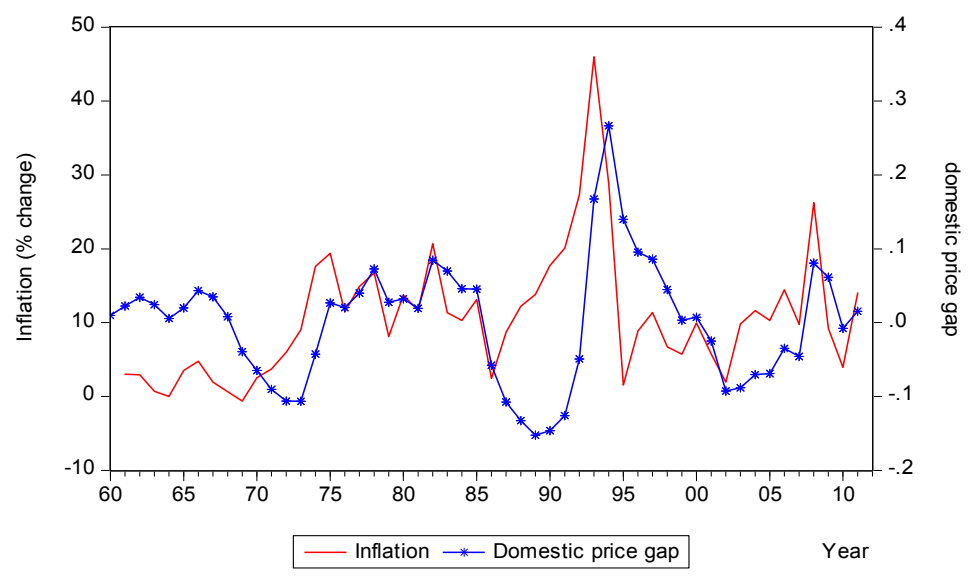

Figure 4. Domestic price gap and inflation

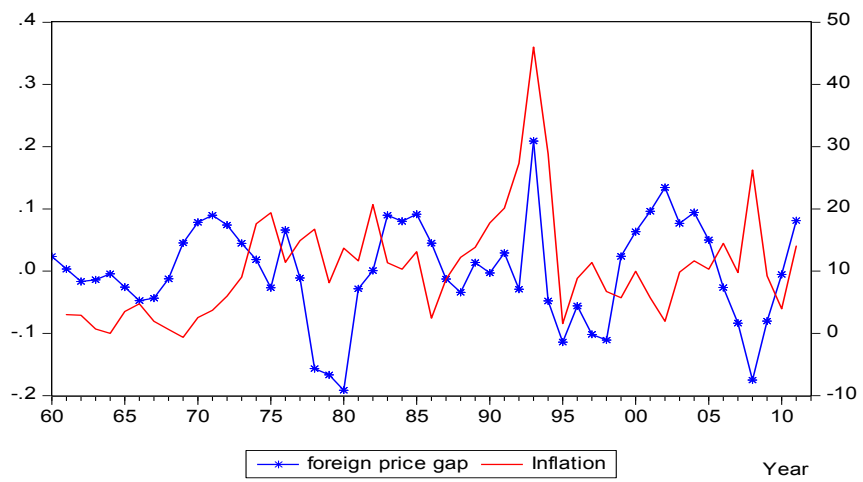

Figure 5. Foreign price gap (logarithmic value) and inflation (\% change)

Unit root tests are given in table 2 and were carried out using Augmented Dickey Fuller and Kwiatkowski-Phillips-Schmidt-Shin (KPSS) tests. The results show that money supply, price level, real exchange rates and world food and fuel prices are integrated of order 1 and hence become stationary upon differencing. Domestic and foreign price gaps as well as output gap are found to be stationary and therefore enter the estimation without differencing.

In the estimation that follows and results displayed in table 3, the P-Star model equations (referred to as models $1 \& 2)$ are compared with alternative inflation equations; namely, two models which incorporate output gap (models $3 \& 4$ ), and a simple univariate autoregressive model (model 5). As shown in figure 6 and based on the partial autocorrelation function (PACF), an autoregressive model of lag order one is found to be sufficient for our analysis. The lag order for the AR model was identified using the partial autocorrelation function and the Akaike information criterion (AIC). 
Table 2. Unit root tests ${ }^{\mathrm{a}}$

\begin{tabular}{ccccc}
\hline Variable & \multicolumn{2}{c}{ levels } & \multicolumn{2}{c}{ Differences } \\
\cline { 2 - 5 } & ADF & KPSS & ADF & KPSS \\
\hline Money, $\log (\mathrm{M})$ & -2.275 & $0.93^{* *}$ & $-6.068^{* *}$ & 0.379 \\
Prices, $\log (\mathrm{P})$ & 0.642 & $0.959^{* *}$ & $-3.522^{*}$ & 0.321 \\
Output, $\log (\mathrm{Y})$ & -1.689 & $0.947^{* *}$ & $-4.845^{* *}$ & 0.326 \\
Real Exchange rate, $\log (\mathrm{RER})$ & -0.517 & 0.164 & $-6.386^{* * *}$ & 0.228 \\
Domestic price gap, (p*-p) & $-3.722^{* *}$ & 0.037 & - & - \\
Foreign price gap (rer-rer*) & $-3.653^{* *}$ & $0.033^{* *}$ & - & $-7.185^{* *}$ \\
Oil price, $\log ($ oilp) & -0.658 & $0.771^{* *}$ & $-5.289^{* *}$ & 0.115 \\
World food price, log(FDP) & -1.409 & $0.66^{*}$ & & \\
Output gap (YGAP) & $-5.198^{* *}$ & 0.041 & & - \\
\hline
\end{tabular}

${ }^{\mathrm{a}} \mathrm{ADF}$ is the augmented Dickey-Fuller test while KPSS is Kwiatkowski-Phillips-Schmidt-Shin test statistic. ${ }^{*}$ indicates $5 \%$ level of significance while ${ }^{* *}$ indicates $1 \%$ level of significance. Significance of the ADF test statistic indicates rejection of the null hypothesis of non-stationarity. The significance of the KPSS statistic implies the opposite, that is, rejection of the null hypothesis of stationarity. In the latter case therefore, rejection implies the series has unit root or is integrated of order (1).

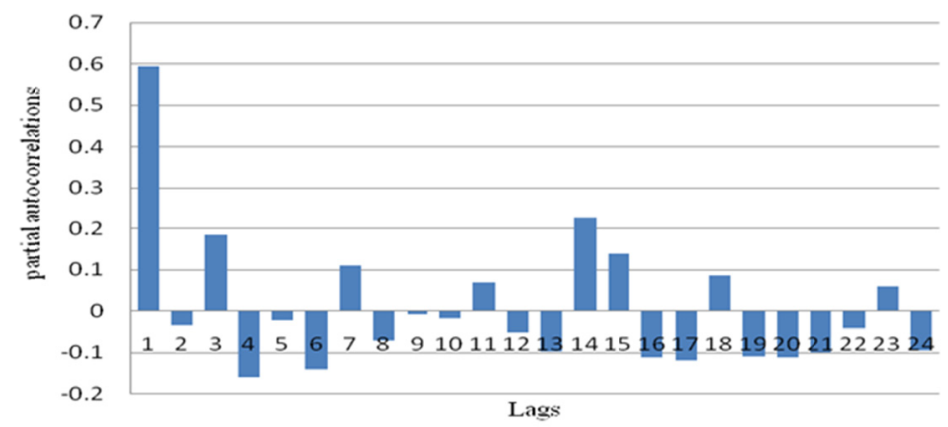

Figure 6. Partial Autocorrelation Function (PACF) for $\Delta \ln P$

As indicated in table 3, out of the estimated models, the first two do test for the significance of the price gap terms, third and fourth models analyze the significance of output gap and the fifth is the univariate autoregressive model. Because of the close association between world food prices and world oil prices, we chose to test the significance of these two variables individually by running separate regressions. For a start, Model 1 incorporates the domestic price gap and foreign price gap. Also included in the estimation are oil prices and two dummy variables to capture effects of exchange rate liberalization in 1993 and the supply shocks related to post election violence combined with onset of the global financial crises of 2008. Model 2 on the other hand is estimated with independent variables which include domestic and foreign price gaps lagged one period, real exchange rate and change in world food prices. Results of the analysis shows that the domestic price gap is highly significant at 1 per cent and has positive effects on inflation with the implied result that a 1 per cent increase in price gap leads in the subsequent period to an increase in inflation by 0.5 per cent. The foreign price gap has negative and insignificant effect on inflation. However, the change in the real exchange rate has highly significant positive effect on inflation. An increase in competitiveness by 1 per cent leads to close to 0.3 per cent inflation in subsequent period. World oil price is significant at 5 per cent level and has expected positive effect on inflation. Two dummy variables are found to be highly significant; dummy variable capturing the exchange rate liberalization of 1993 and the post election violence of 2008 both of which had the effect of raising inflation. In model 2, World food prices have significant positive effects on inflation. A 1 per cent increase in world food prices however leads to 0.08 per cent inflation compared to 0.03 per cent inflation resulting from 1 per cent fuel price increase. Past inflation contributes significantly to current inflation suggesting a high level of persistence of inflation. High inflation will therefore persist into the future. Overall, domestic price gap is more significant in Kenya's case than the foreign price gap in predicting inflation. This complements the findings by Kool and Tatom (1994) who find that the domestic price gap is more important in flexible exchange rate regimes.

The insignificance of the foreign price gap suggests that agents consider the deviation from equilibrium of the real exchange rate as transitory and thus more likely to reverse in the period ahead. Theoretically, as the real exchange rate depreciates beyond its long-run level, aggregate demand is expected to increase. The increase in 
aggregate demand consequently pushes up domestic prices owing to increased cost of imported inputs and upward price adjustments by local firms which produce import substitutes and possibly second round effects of higher wage demands. The increase in prices of domestic goods leads to an appreciation of the real exchange rate thus pushing the real exchange rate back to its long-run level. On the other hand, if the real exchange rate is more appreciated than its long-run level, aggregate demand declines, domestic prices fall and the real exchange rate depreciates towards its long-run level. Based on the definition of the exchange rate in this paper, a more depreciated exchange rate is expected to move downwards towards equilibrium level in response to aggregate demand changes while a more appreciated exchange rate is expected to move upwards towards equilibrium. Any deviation from equilibrium is therefore followed by aggregate demand changes which in effect reverse the deviation from equilibrium, thus suggesting that the real exchange rate deviation is transitory in nature. Similar views have been expressed in Cerisola and Gelos ((2005) in their study of inflation in Brazil. They found that longer lags of the real exchange rate result in negative signs suggesting transitory nature of real exchange rate deviations from equilibrium.

Table 3. Parameter estimates: P-Star Models (models 1\&2), models incorporating output gap (models 3\&4) and univariate autoregressive model (model 5)

Dependent variable: first difference of $\log (\mathrm{P}),(\Delta \ln \mathrm{P})$

\begin{tabular}{|c|c|c|c|c|c|}
\hline & Model 1 & Model 2 & Model 3 & Model 4 & Model5 \\
\hline Constant & $0.003(0.008)$ & $0.006(0.009)$ & $0.033(0.012)^{* * *}$ & $0.049(0.011)^{* * *}$ & $0.045(0.011)^{* * *}$ \\
\hline$\Delta \ln \mathrm{P}_{\mathrm{t}-1}$ & $0.552(0.059)^{* * *}$ & $0.546(0.062)^{* * *}$ & $0.424(0.086)^{* * *}$ & $0.439(0.085)^{* * *}$ & $0.488(0.128)^{* * *}$ \\
\hline$\Delta \ln \mathrm{P}_{\mathrm{t}-3}$ & $0.346(0.061)^{* * *}$ & $0.360(0.064)^{* * *}$ & - & - & \\
\hline$(p-p *)_{t-1}$ & $0.449(0.06)^{* * *}$ & $0.474(0.062)^{* * *}$ & - & - & \\
\hline$(\text { rer-rer* })_{\mathrm{t}-1}$ & $-0.075(0.056)$ & $-0.080(0.059)$ & - & - & \\
\hline$\Delta \ln R E R_{\mathrm{t}-1}$ & $0.273(0.052)^{* * * *}$ & $0.273(0.056)^{* * * *}$ & $0.282(0.07)^{* * *}$ & $0.268(0.078)^{* * *}$ & \\
\hline$\Delta \operatorname{lnOilp}_{\mathrm{t}}$ & $0.037(0.014)^{* * *}$ & 年 & $0.049(0.021)^{* *}$ & & \\
\hline$\Delta \operatorname{lnOilp}_{\mathrm{t}-1}$ & $0.0263(0.014)^{* * *}$ & - & $0.039(0.02)^{*}$ & & \\
\hline Dum1993 & $0.026(0.029)^{* * *}$ & $0.172(0.031)^{* * *}$ & $0.239(0.042)^{* * *}$ & $0.258(0.045)^{* * *}$ & $0.215(0.023)^{* * *}$ \\
\hline Dum2008 & $0.180(0.028)^{* * *}$ & $0.138(0.029)^{* * *}$ & $0.149(0.042)^{* * *}$ & $0.142(0.044)^{* * *}$ & $0.142(0.007)^{* * *}$ \\
\hline$\Delta \operatorname{lnFDP} \mathrm{t}_{\mathrm{t}-1}$ & - & $0.076(0.031)^{* *}$ & & $0.129(0.055)^{* *}$ & \\
\hline$\Delta \operatorname{lnFDP} P_{t-4}$ & & & & $0.114(0.056)^{* *}$ & \\
\hline YGAP & & & $0.361(0.183)^{*}$ & & \\
\hline $\mathrm{YGAP}_{\mathrm{t}-1}$ & & & & $0.353(0.186)^{*}$ & \\
\hline $\mathrm{R}_{\text {adj. }}^{2}$ & 0.872 & 0.86 & 0.71 & 0.68 & 0.58 \\
\hline D.W. & 2.127 & 1.94 & 1.52 & 1.74 & 1.79 \\
\hline $\begin{array}{c}\text { Serial } \\
\text { correlation LM } \\
\text { test (p value) }\end{array}$ & $\mathrm{F}=0.171(0.843)$ & $1.444(0.249)$ & $2.199(0.125)$ & $1.222(0.306)$ & $0.924(0.405)$ \\
\hline $\begin{array}{l}\text { Normality test } \\
\quad(p \text { value })\end{array}$ & $\begin{array}{c}\mathrm{J}-\mathrm{B}=2.039 \\
(0.361)\end{array}$ & $0.179(0.914)$ & $0.463(0.793)$ & $0.974(0.614)$ & $1.93(0.381)$ \\
\hline $\begin{array}{l}\text { Heteroskedastic } \\
\text { ity test } \\
\text { (p-value) }\end{array}$ & $\mathrm{F}=0.731(0.678)$ & $0.518(0.836)$ & $1.19(0.33)$ & $0.888(0.525)$ & $2.654(0.06)$ \\
\hline $\begin{array}{l}\text { RESET test } \\
\text { (p-value) }\end{array}$ & $\begin{array}{c}F=0.544 \\
(0.465)\end{array}$ & $0.024(0.861)$ & $0.292(0.593)$ & $0.175(0.678)$ & $1.27(0.266)$ \\
\hline AIC & -4.199 & -4.135 & -3.442 & -3.369 & -3.076 \\
\hline $\mathrm{SC}$ & -3.802 & -3.802 & -3.091 & -3.054 & -2.923 \\
\hline
\end{tabular}

Note: Standard errors of estimates appear in the parentheses. ${ }^{*}$ signify $10 \%$ significant levels, ${ }^{* *}$ signify $5 \%$ significant levels while ${ }^{* * *}$ signify $1 \%$ significance level. Residual normality is tested using Jarque-Bera (J-B) statistic. AIC and SC are Akaike Information Criterion and Schwarz Criterion respectively.

Models 3 \& 4 show estimated results for two inflation models which incorporate output gap with one incorporating also oil prices and another world food prices as proxy for world commodity prices. In model3, the output gap turns out to be significant at 10 per cent level of significance. Current and previous changes in the log of oil prices are found to be significant at 1 per cent and 5 per cent levels of significance respectively. The change in the real exchange rate remains highly significant at 1 per cent level of significance. In model 4 , output 
gap was found to be significant also at 10 per cent level of significance. First and fourth lags of food prices are significant at 5 per cent level of significance. The change in real exchange rates is highly significant at 1 per cent level of significance. The same applies to the two dummy variables which remain significant at 1 per cent level of significance. The first lag of inflation is also highly significant at 1 per cent level of significance, confirming once again inflation persistence. In the simple univariate autoregressive model (model 5), lagged inflation is highly significant at 1 per cent significance level. The two dummy variables are also highly significant at 1 per cent level of significance as in the other models. The information criterion for each model is given which clearly indicate that the P-Star model is more parsimonious going by the maximized log likelihood function of Akaike Information Criterion (AIC) and Schwarz Criterion (SC) for models 1 and 2 compared to models 3, 4 and 5.

In summing up, the following key results are derived:

- Domestic price gap is significant at 1 per cent significance level.

- The coefficient on foreign price gap is negative and insignificant. However, the coefficient on the change in real exchange rates is positive and highly significant at 1 per cent significance level.

- Past inflation is highly significant at 1 per cent significance level across the estimated models.

- Change in the log of world oil prices is highly significant at 1 per cent significance level.

- Change in the log of lagged world food prices is significant at 5 per cent significance level.

- Output gap is significant at 10 per cent level of significance.

Next, a forecast evaluation is carried out comparing the forecasts of the five alternative models; the two P-star model variants, the two model variants which incorporate output gap and the simple univariate autoregression model (see table 4 and figures 7-11). In the evaluation, static model solutions and dynamic model solutions are obtained and compared across models. The Static model solution is basically a one-step-ahead forecast while the dynamic solution allows for multi-step ahead forecasts. The forecast evaluation is based on five measures: root mean squared error, mean absolute error, theil inequality as well as bias and variance proportions. The P-star model outperforms forecasts of the rest of the models. The P-star model has lower forecasting error and the mean and variance of the forecasts closely approximate actual values. This finding holds for both set of forecasts from static and dynamic model solutions. Figures 7-11 show the dynamic solution to models 1-5, again demonstrating the superior forecasting performance of the P-Star model.

Table 4. Inflation forecast evaluation

\begin{tabular}{|c|c|c|c|c|c|c|c|c|c|c|}
\hline & \multicolumn{2}{|c|}{$\begin{array}{c}\text { Root mean } \\
\text { squared error }\end{array}$} & \multicolumn{2}{|c|}{ Mean absoluteerror } & \multicolumn{2}{|c|}{$\begin{array}{c}\text { Theil inequality } \\
\text { coefficient }\end{array}$} & \multicolumn{2}{|c|}{ Bias proportion } & \multicolumn{2}{|c|}{$\begin{array}{l}\text { Variance } \\
\text { proportion }\end{array}$} \\
\hline & static & dynamic & static & dynamic & static & dynamic & static & dynamic & Static & dynamic \\
\hline Model 1 & 0.024 & 0.025 & 0.019 & 0.019 & 0.094 & 0.100 & 0.000 & 0.054 & 0.027 & 0.000 \\
\hline Model 2 & 0.025 & 0.031 & 0.020 & 0.025 & 0.101 & 0.124 & 0.000 & 0.031 & 0.032 & 0.001 \\
\hline Model 3 & 0.036 & 0.044 & 0.029 & 0.035 & 0.144 & 0.180 & 0.000 & 0.000 & 0.068 & 0.222 \\
\hline Models 4 & 0.038 & 0.046 & 0.031 & 0.037 & 0.151 & 0.184 & 0.000 & 0.000 & 0.078 & 0.186 \\
\hline Models 5 & 0.048 & 0.059 & 0.038 & 0.048 & 0.200 & 0.252 & 0.000 & 0.000 & 0.135 & 0.336 \\
\hline
\end{tabular}

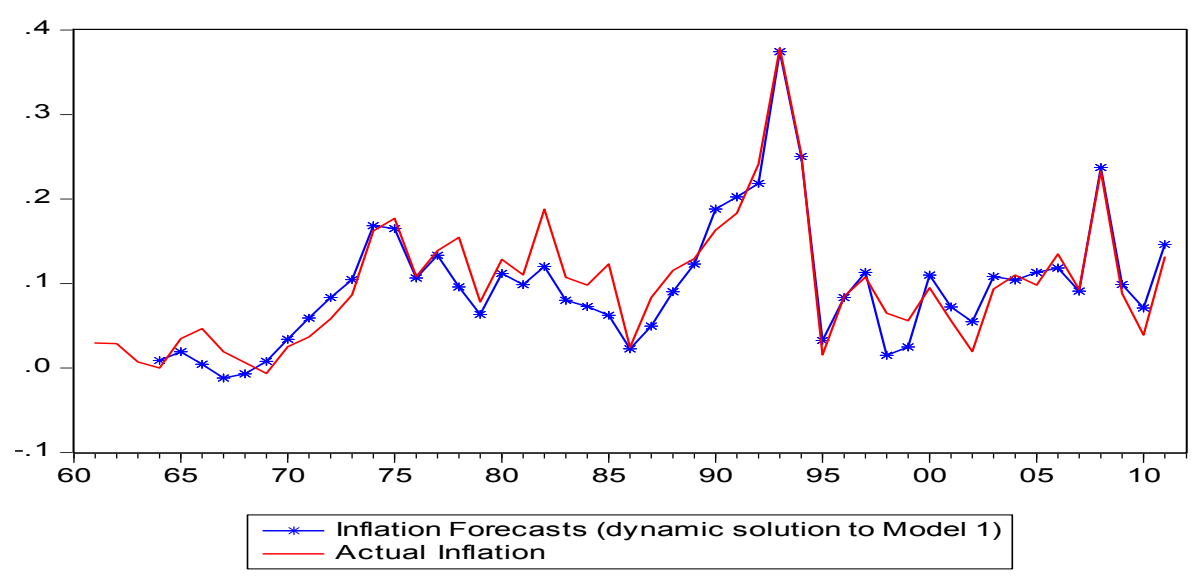

Figure 7. Model 1 Inflation forecasts (dynamic solution of the model) 


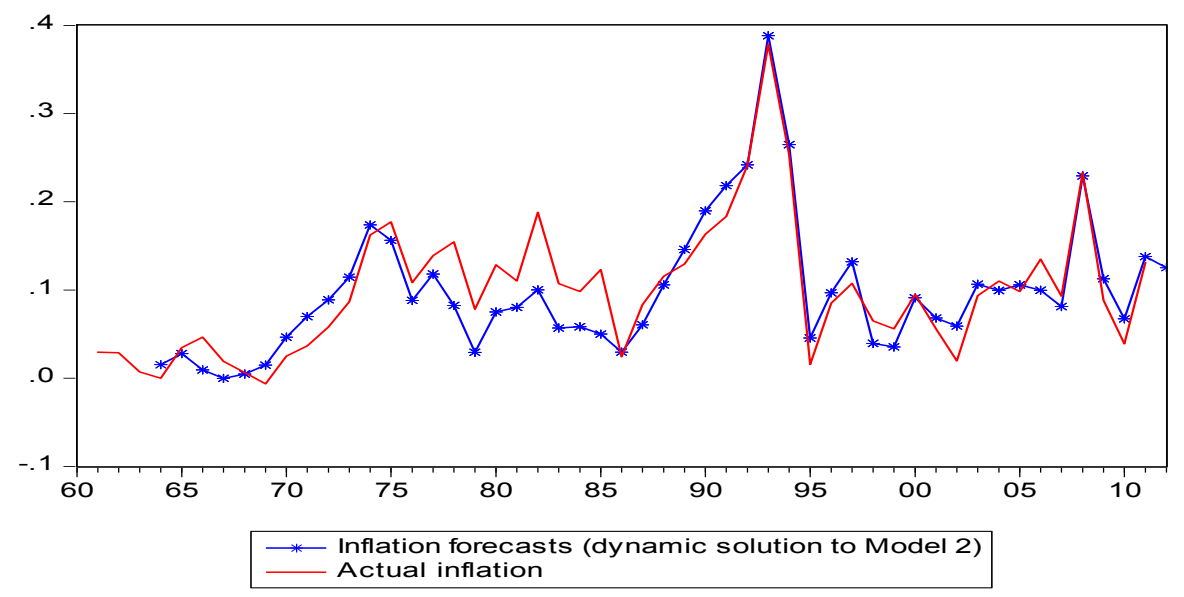

Figure 8. Model 2 inflation forecasts

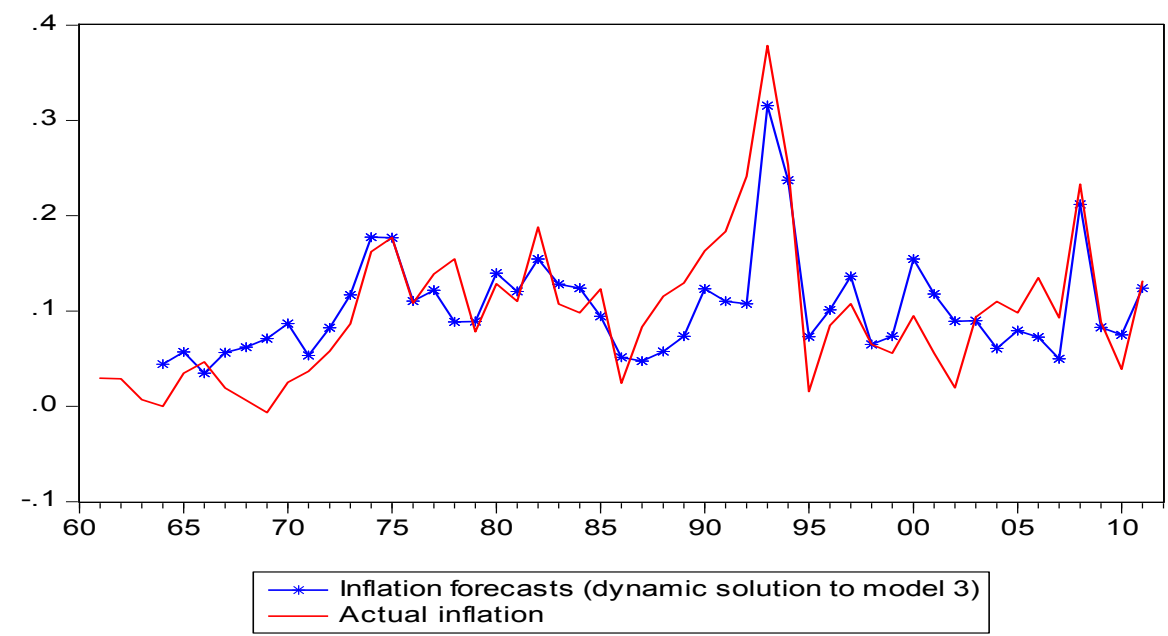

Figure 9. Model 3 inflation forecasts

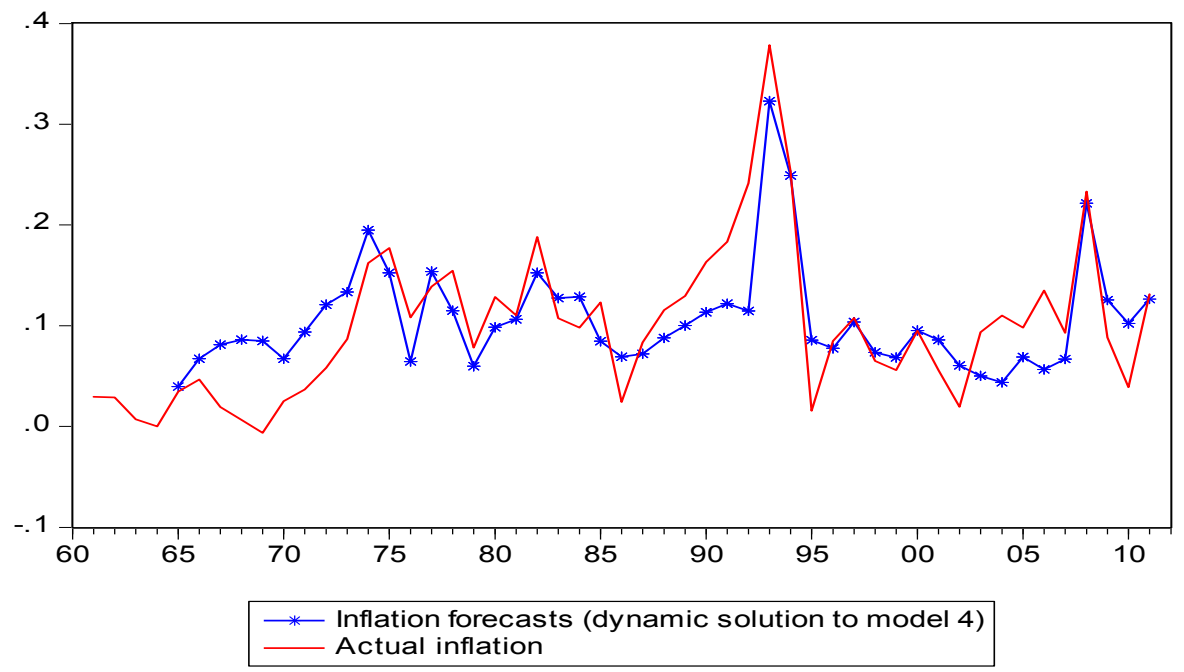

Figure 10. Model 4 inflation forecasts 


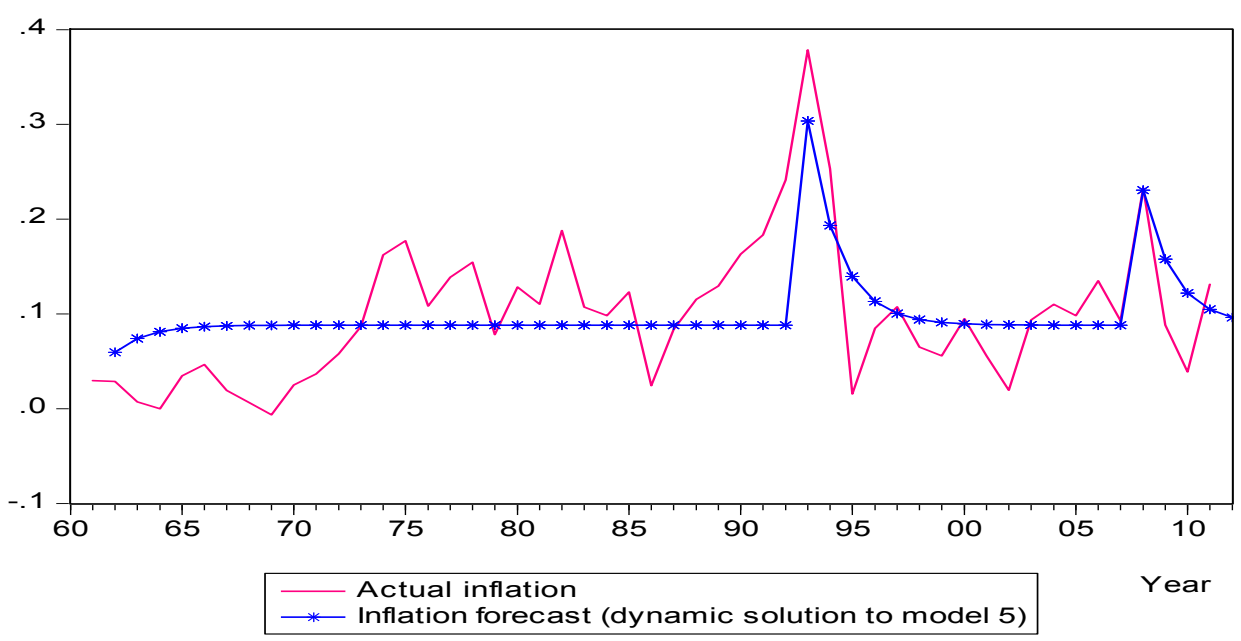

Figure 11. Model 5 inflation forecasts

\section{Conclusions and Policy Implications}

This study extends the P-Star methodology by applying an alternative approach to the derivation of the foreign price gap. The analysis uses Kenyan data over the period from 1960 to 2011 to test the relevance and performance of the P-Star model in the Kenyan context. Results of the analysis show that the domestic price gap is highly significant at 1 per cent and has positive effect on inflation with the implied result that a 1 per cent increase in price gap leads in the subsequent period to an increase in inflation by 0.5 per cent. The foreign price gap has negative and insignificant effect on inflation. However, the change in the real exchange rate has highly significant positive effects on inflation. An increase in competitiveness by 1 per cent leads to close to 0.3 per cent inflation in subsequent period. World oil price is significant at 5 per cent level and has expected positive effect on inflation. Similarly, world food prices have significant positive effects on inflation. A 1 per cent increase in world food prices leads to 0.08 per cent inflation compared to 0.03 per cent inflation resulting from 1 per cent fuel price increase. Exchange rate liberalization of 1993 and the post election violence of 2008 also had significant positive effects on inflation. Past inflation contributes significantly to current inflation suggesting a high level of persistence of inflation. Overall, the domestic price gap is found to be more significant in predicting Kenya's rate of inflation when compared with the foreign price gap.

The results arising from a forecast evaluation indicates that the P-star model outperforms forecasts of other alternative inflation models for Kenya. The P-star model has lower forecasting error and the mean and variance of the forecasts closely approximate actual values. This finding holds for both set of forecasts from static and dynamic model solutions.

On the policy front, it can be argued that Kenya's inflation in the medium to long-term is driven by domestic developments though in the short-term other factors too play a role. Such short-term movements in inflation could result from price developments abroad and real exchange rate changes. In the long-term however, domestic factors dominate as evidenced by the significance of the dometsic price gap and the relevance of the P-Star model. Bearing in mind that P-Star is tied to long-term monetary developments and potential output, the results in this study underscore the usefulness of the P-Star approach in providing forecasts of inflation and thus serving as source of leading indicator of inflation for Kenya. Such an indicator would present the opportunity to effect policy change in a timely manner hence making it possible to achieve price stability and ensure consistency between monetary policy decisions and the prevailing macro environment.

\section{References}

Atta-Mensah, J. (1996). A modified P*-Model of inflation based on M1. Working paper 96-15, Bank of Canada. http://dx.doi.org/10.2139/ssrn.56188

Cerisola, M., \& Gelos, R. G. (2005). What drives inflation in Brazil? An empirical analysis. IMF Working Paper WP/05/109. Retrieved from http://www.imf.org/external/pubs/ft/wp/2005/wp05109.pdf

Christiano, L. J. (1989, Autumn). P* is not the inflation forecaster's holy grail. Federal Reserve Bank of Mineapolis Quarterly Review, 13, 3-18. Retrieved from http://minneapolisfed.org/research/qr/qr1341.pdf 
Frait, J., Komárek, L., Kulhánek, L., \& Yurkovsky, A. (2000). An analysis of inflation in the Czech Republic using the $\mathrm{P}^{*}$ model. Eastern European Economics, 38(4), 54-72. Retrieved from http://www.jstor.org/stable/pdfplus/4380227.pdf?acceptTC=true

Hallman, J. J., Porter, R. D., \& Small, D. H. (1991). Is the price level tied to the M2 monetary aggregate in the long run? The American Economic Review, 81(4), 841-858. Retrieved from http://www.jstor.org/stable/pdfplus/2006645.pdf

Hoeller, P., \& Poret, P. (1991, Autumn). Is P-Star a good indicator of inflationary pressure in OECD countries? OECD Economic studies, 17, 7-29. Retrieved from http://www.oecd.org/eco/outlook/34254867.pdf

Kamin, S. B., \& Klau, M. (2003). A multi-country comparison of the linkages between inflation and exchange rate competitiveness. International Journal of Finance and Economics, 8, 167-184. http://dx.doi.org/10.1002/ijfe.205

Koenig, E. F. (1994). The P* Model of inflation revisited. Working Paper 94-14. Research Department, Federal Reserve Bank of Dallas. Retrieved http://dallasfed.org/assets/documents/research/papers/1994/wp9414.pdf

Kool, J. M., \& Tatom, J. A. (1994). The P-Star model in five small economies. Federal Reserve Bank of ST. Louis Review. Retrieved from http://research.stlouisfed.org/publications/review/1994index.html

Lim, C. H., \& Papi, L. (1997). An econometric analysis of the determinants of inflation in Turkey. IMF Working Paper WP/97/170. Retrieved from http://www.imf.org/external/pubs/ft/wp/wp97170.pdf

Mehra, Y. P. (1988 September/ October). The forecast performance of alternative models of inflation. Federal Reserve Bank of Richmond Economic Review. Retrieved from http://ssrn.com

Pallardo, V. J., \& Esteve, V. (1999). The P-star model and its performance for the Spanish economy. Working paper 99/11. Universidad de Valencia. Retrieved from http://www.uv.es/fatwirepub/userfiles/file/PDF11.pdf

Quyyum, A., \& Bilquees, F. (2005). P-Star model: A leading indicator of inflation for Pakistan. The Pakistan Development Review, 44(2), 117-129. Retrieved from http://mpra.ub.uni-muenchen.de/2058/

Scheide, J., \& Trabandt, M. (2000). Predicting inflation in Euroland-The Pstar approach. Working Paper 1019. Kiel Institute of World Economics. Retrieved from http://www.ifw-members.ifwkiel.de/publications/predicting-inflation-in-euroland-the-p-star-approach/kap1019.pdf

Tsionas, E. G. (2000). P-STAR analysis in a converging economy: The case of Greece. Economic Modelling, 18, 49-60. Retrieved from http://www.sciencedirect.com/science/article/B6VB1-42348R8-3/2/abc8ef68d08fcc2182386afd0875d1cd

\section{Notes}

Note 1. Partial adjustment of real exchange rates.

We assume a partial adjustment of actual real exchange rates to its long-run level or equilibrium. Hence,

$$
\begin{gathered}
\log \left(\frac{P_{t}^{F}}{P_{t}^{H}}\right)=\log \left(\frac{P_{t-1}^{F}}{P_{t-1}^{H}}\right)+\lambda\left[\log \left(\frac{P_{t-1}^{F^{*}}}{P_{t-1}^{H *}}\right)-\log \left(\frac{P_{t-1}^{F}}{P_{t-1}^{H}}\right)\right] \\
\log P_{t}^{F}-\log P_{t}^{H}=\log P_{t-1}^{F}-\log P_{t-1}^{H}+\lambda \log \left(\frac{P_{t-1}^{F^{*}}}{P_{t-1}^{H^{*}}}\right)-\lambda \log \left(\frac{P_{t-1}^{F}}{P_{t-1}^{H}}\right) \\
-\log P_{t}^{H}+\log P_{t-1}^{H}=-\log P_{t}^{F}+\log P_{t-1}^{F}+\lambda \log \left(\frac{P_{t-1}^{F^{*}}}{P_{t-1}^{H^{*}}}\right)-\lambda \log \left(\frac{P_{t-1}^{F}}{P_{t-1}^{H}}\right) \\
\log P_{t}^{H}-\log P_{t-1}^{H}=\log P_{t}^{F}-\log P_{t-1}^{F}+\lambda\left(\log \left(\frac{P_{t-1}^{F}}{P_{t-1}^{H}}\right)-\log \left(\frac{P_{t-1}^{F *}}{P_{t-1}^{H *}}\right)\right) \\
\Delta \log P_{t}^{H}=\Delta \log P_{t}^{F}+\lambda\left[\log \left(\frac{P_{t-1}^{F}}{P_{t-1}^{H}}\right)-\log \left(\frac{P_{t-1}^{F^{*}}}{P_{t-1}^{H}}\right)\right]
\end{gathered}
$$

Note 2. Kool and Tatom (1994) measure of foreign price gap.

Kool and Tatom (1994) measure is derived from exchange rate constraint and based on assumption of purchasing 
power parity in the long run such that:

$$
P_{t}^{H^{*}}=\frac{P_{t}^{F^{*}}}{R E R_{t}^{*}}
$$

Where, RER is real exchange rate while the other variables are as defined above.

Consequently,

$$
\text { Foreign price gap }=\log P_{t}^{H}-\log P_{t}^{H^{*}}=\left(\log P_{t}^{F^{*}}-\log R E R_{t}^{*}\right)-\log P_{t}^{H}
$$

\section{Copyrights}

Copyright for this article is retained by the author(s), with first publication rights granted to the journal.

This is an open-access article distributed under the terms and conditions of the Creative Commons Attribution license (http://creativecommons.org/licenses/by/3.0/). 